YAK 347.4

DOI https://doi.org/10.32837/chc.v0i39.374

Гуйван Петро Амитрович,

канАиАат юридичних наук, заслужений юрист України, професор

Полтавського інституту бізнесу

ORCID ID: 0000-0003-3058-4767

\title{
ЮРИДИЧНЕ ЗНАЧЕННЯ ДОБРОЇ СОВІСТІ ДЛЯ ДАВНІСНОГО ВОЛОДІЛЬЦЯ, ЙОГО ОБґРУНТУВАННЯ З ПОЗИЦІї КОНЦЕПЦІї ВИДИМОСТІ ПРАВА
}

Постановка проблеми. Аля визначеності правового статусу суб'єкта, що утримує майно, стосовно якого він не має титулу, важливою обставиною $\epsilon$ наявність у нього добросовісного стану. Розгортання цивільного обороту створило юриАичні інструменти, що забезпечують захист володільця проти власника. Це такі інструменти, як набувальна давність, набуття власності в момент отримання майна віА неповноважного відчужувача, обмеження вінАикації. Усі ці засоби пов'язані між собою, і в основі кожного з них перебуває добра совість набувача. При цьому в українському законодавстві юридичне значення надається добрій совісті саме на час набуття речі, а не при подальшому володінні нею. Аобра совість незаконного окупанта має значення на момент отримання чужого майна. Втрата добросовісності в подальшому (повіАомлення володільця про існування реального власника, преА'явлення віндикаційного позову тощо) не впливає на правовий статус набувача.

Аналіз останніх АосліАжень і публікацій. Питанням наукового АосліАженя Аобросовісності набуття чужої речі та ї̈ проявів піА час Аавнісного володіння присвячені праці таких науковців, як $\Lambda$. Эннекцерус, П. Ертманн, Г.Ф. Шершеневич, К.І. Ск^овський, А.В. АожАьов, В.П. Маковій та інші. ВоАночас питання залишається вельми актуальним, адже сучасне законодавство не дає чіткої відповіді на Аеякі запити реальної практики. Скажімо, не визначено правове значення Аоброї совісті Аавнісного волоАільця в процесі його протиАії вимогам власника про витребування речі, не набули однозначної оцінки Аіяння окупанта, які той мусить чинити, аби Аотриматися вимоги закону про віАкритість володіння. Усе це має істотний вплив на результативність застосування інституту набувальної давності, і у такий спосіб - поліпшення Аинаміки матеріальних віАносин. У Ааній праці вказані питання АосліАжуються, вихоАячи з того важливого принципу, що фактичні відносини мають регулюватися з урахуванням їхньої правової співмірності.

Тож метою роботи $€$ правове обгрунтування юриАичних способів Аля Аосягнення оптимального співвідношення між задоволенням інтересу особи, що втратила володіння, та інтересу добросовісного набувача майна.

ВикиаА основного матеріалу. Аобра совість особи - це такий стан їі волі, який характеризується вибачливим незнанням про об'єктивні перешкоди Аля Аосягнення поставленої юридичної мети, зокрема придбання приватного права [1, с. 81]. ВіАповіАно, недобросовісний володілець (malae fidei possessor) знає або мусить знати, що він володіє чужим майном [2, с. 484]. Отже, наразі саме критерій Аобросовісності надає істотного значення претензіям учасників даних взаємин на набуття чи збереження приватного речового права. Попри юридичне значення доброї совісті на момент заволодіння чужою річчю, що надає правової визначеності можливості оформлення титулу і $є$ склаАовою частинного фактичного складу Аля набуття власності чи права Аавнісного волоАіння, Аобросовісність володіння чужою річчю також характеризує порядок повеАінки окупанта і впродовж набувальної давності. У цій якості вона впливає не на спосіб здійснення права, а на його 
стан у суб'єктивному сприйнятті самого утримувача майна. При цьому, на наше переконання, юридична категорія Аобросовісності (bona fides) не може набувати занадто широкого тлумачення, яке б фактично ототожнювало його з не зловживанням правом, загальною повагою до правопорядку тощо. Якщо упродовж тривалості давнісного володіння суб'єкт Аізнається, що його окупація не мала ознак Аобросовісності, хоча він про те не знав раніше, його правовий статус не зміниться. Відтак не можна погодитися, що недобросовісність особи у будь-якому разі може мати наслідком втрату можливості його захисту [3, с. 49].

Разом із тим не сліА забувати, що особа, яка добросовісно заволоділа чужим майном і подовжує Аавнісне володіння, не отримує права власності, поки встановлений законом строк не спливе. У такому разі протягом його перебігу вона набула можливість утримувати річ не тому, що має віАповіАне право, а незважаючи не віАсутність його [4, с. 273]. Більш того, як правильно вказує К.І. Скловський, Аобра совість у речових відносинах є чинником, притаманним виключно тій особі, яка протистоїть праву. Аійсно, абсо^ютно неАоцільним та зайвим вигляАає АовеАення наявності доброї волі в носія суб'єктивного права, наприклаА, у кредитора за зобов'язанням чи власника. Встановлення та доведення Ааного факту жодним чином не вплине на правову ситуацію [5, с. 60]. На практиці суб'єктові права немає потреби спиратися на свою bona fides, a тим більше їі Аоводити чи навіть презумувати, бо особі, яка йому протистоїть, треба оспорювати саме суб'єктивне право. Отже, тільки тоді, коли Аобра совість протиставлена праву, вона придбаває безпосереднє юридичне значення, в тому числі і як умова набуття та захисту права.

Ситуацію з фактичним володінням особою чужим майном без належного права численні АосліАники намагалися практично вирішити на основі наукової концепції видимості права. За нею показна видимість права, власне, заміняє правове володіння. Як свідчить наукова практика, нею вже Аавно і стабільно визнається той важливий принцип, що фактично існуюче явище у житті має враховуватися навіть без його правової співрозмірності та іноді і всупереч істинному праву. При цьому Аавність також розгляАається як наслідок видимості права, попри те, що в канонічному законодавстві вона виникає та триває всупереч волі учасників відносин та незважаючи на їхнє усвідомлення цього факту. Вважається, що добросовісне безперервне та відкрите володіння майном як власним упродовж строку набувальної Аавності найпоказовіше пов'язувалось із видимістю власності. Цьому, зокрема, сприяє і саме визначення відкритості утримання майна, яке в багатьох мегіслатурах тлумачиться якості володіння, як власність.

Аобросовісність володіння чужою річчю $є$ внутрішнім показником усвідомлення певного майнового стану самим суб'єктом. Вважаючи себе законним набувачем речі, пізнаючи соціальну цінність власної особистості, він одночасно визнає автономію контрагента, виявляє повагу до нього. І якраз таким ось чином Ааний суб'єкт забезпечує міцність створеного ним матеріального зв'язку. Отже, поняття Аобросовісності є, власне, виявом конформності щодо принципів справеАливості, усвідомлених та сприйнятих особою на рівні індивідуальних ціннісних орієнтацій [6, с. 97]. Аана ознака речового права з метою прояву ії назовні тісно пов'язана із принципом захисту видимості права. Така видимість має бути спрямована саме на ії̈ сприйняття третіми особами. Останні, бачачи, що річ перебуває у володінні, мають зробити висновок, що вона є об'єктом права власності утримувача [7, с. 185]. Звісно, насправАі, існує юридична віАмінність між власністю та її зовнішнім суспільним проявом - володінням, та Аля цілей стабілізації обороту вона не має принципового значення, бо така умова санкціонована нормативно [8, с. 42]. Зрештою, інститут набувальної Аавності і покликаний усунути подібні розбіжності після спливу встановленого строку.

Як ми вже казали, українське законодавство не вимагає обов'язковості внутрішньої взаємодії володільця з об'єКтом володіння як із власним та Аобросовісності суб'єкта протягом усього часу володіння. Можемо припустити, що віА якогось моменту володілець буде цілком усвіАомлювати Аефект неправомірного утримання речі. Але й налалі у відкритості володіння буде проявлятися об'єктивна очевидність Аля третіх осіб законності права, за яку вони приймають зовнішню видимість права власності. При цьому існують певні відмінності в застосуванні теорії видимості права при набутті власності Аобросовісним набувачем віА неповноважного відчужувача та за набувальною Аавністю. Такі віАмінності торкаються, головним чином, сфери майнового обігу. Так, у першому випадку істотне значення має видимість наявності повноваження у особи, з якою набувач вчиняє правочин, тоді як при набутті власності за давністю вже у набувача існує видимість власного права, 
яка з часом перетворюється у Аійсне право. Тут Аовіра до видимості права виникає не внаслідок поведінки псевдоуповноваженого, а в результаті тривалого належного відношення особи до речі, як Ао власної. Іншими словами, правовизначальним фактором є належність самого волоАіння, а не його походження. ВіАтак навряА чи правильно ототожнювати відкритість та добросовісність Аавнісного володіння [9, с. 10], оскільки останній чинник не впливає на можливість набуття права власності на майно. Разом із тим, зважаючи на фактично однаковий юридичний результат, окремі науковці пропонують кваліфікувати застосування видимості права Аля набувальної Аавності як певний юридичний ерзац, покликаний замінити негайне придбання власності більш складним правовим механізмом [10, с. 273-275] На наше переконання такий варіант $€$ неприйнятним: повторимо, набуття в^асності добросовісним суб'єктом віА неповноважного продавця та за набувальною давністю суть різні матеріально-правові явища. Набувальна Аавність застосовується якраз там, де віАсутня можливість негайного набуття власності в результаті добросовісної окупації речі.

Феномен припущення про видимість права та його ефективність має те значення, що воно ґрунтується на визнанні фактично існувавших відносин як піАстави Аля правового перетворення. Такий насліАок є практично тотожним із правовим результатом юридичної презумпції, при цьому все ж має отримати обґрунтування та вказані підстави виникнення подібної Аійсності. В усякому разі такий механізм мусить застосовуватися піА час презумування віАношення Ао речі як власної з боку володільця рухомого майна. Утім, подібне передбачення як видимість права втрачає практичний сенс, коли буде встановлено, що річ вибула віА власника проти його волі, і він бажає віндикувати ії Ао спливу позовної Аавності. Іншими словами, теза про видимість права не повинна Аіяти всупереч реальному праву власності, яке не є пасивним та було припинене в частині володіння з дефектом волі носія. Прирівнювання категорії “правове волоАіння" Ао виАимості реального права Аозволяє запровадити захист володіння в межах власницького захисту. Але при цьому неодмінно виникає низка проблем. Зокрема, якщо видимість права заміняє саме право, яке де-факто належало іншій особі, мають бути встановлені певні критерії такої заміни. Інакше існує великий ризик суб'єктивізму і сваволі. Це розуміють і АосліАники питання.
Виглядає абсолютно неприпустимою думка в дусі ідей вільного права без найменшого позитивно-правового поширення володіння вілразу на всі випаАки видимості такими, що відповідають праву [10, с. 280-285].

Водночас необхінно констатувати, що реально на практиці піА час захисту володіння акценти робляться на користь фактичного стану речей, який полягає в пануванні наА річчю. I то відбувається часто всупереч праву, навіть безспірному та очевидному. Відтак убачається, що поняття видимості права мусить мати не необмежене застосування, а використовуватися у випадках, коли певний правопорядок наАає захист передбачуваній власності, або володінню, яке за своєю природою розглядається як таке, що потребує захисту як ерзац власності. Коли в такому разі дане володіння має якесь правове обґрунтування (наприклаА, Аавнісне), то захищається вже не як видимість права, а заради нього самого. Це $€$ проявом фактичного суспільного порядку який не повинен бути похитнутий суб'єктивізмом та самоуправством. Вказане право на захист все ж мусить віАрізнятися віА того, що притаманне істинному власникові. Володіння, хоча і створює захисну можливість у вигляді права, надає останньому значення похідного, тимчасового, бо саме охоронюване повноваження може бути підАане петиторному Аомаганню Аійсного власника. Отже, правові наслідки фактичної окупації у вигляді встановлення захисної можливості посесорного характеру витікають із статусу кво як такого, і створюють більш м'які загальні умови, тоді як видимість права Аіє індивіАуально залежно віА конкретних їі проявів стосовно мише того, хто їй Аовіряє. Ця Аовіра зумовлює захист тією мірою, в якій виАимість була створена власною поведінкою уповноваженої особи або влаАним приписом чи аАміністративним актом. Власне, і практичні наслідки цих Авох піАходів Є різними: піА час застосування механізму видимості права вони більш сильні, особа, що захищається за допомогою неї, отримує недоторканість, належну власникові. А володільницький посесорний захист надає набувачу мише певне, віАмінне віА оригінального охоронне право.

Як бачимо, між Аавністю як станом набувального власницького правового інституту і насліАками видимості права є багато значних розбіжностей. Але повністю віАкиАати значення цього принципу у процесі незаконної Аобросовісної окупації і подальшого утримання речі, звісно, не можна. Так, має серйозне значення видимість Аля покупця наявності повноважень в особи, 
з якою останній укладає угоду про відчуження речі. У Ааному випадку видимість пов'язана виключно з тим аспектом, наскільки певні правові наслідки у вигляді набуття права можуть виникнути в результаті угоА у комерційному обороті, коАи контрагент не відповідає всім умовам, недотримання яких в інших випадках тягне неАійсність відношення. Тож Аостатність окремих проявів видимості права, які надають можливість у такому випадку уявити наявність відсутніх у Аійсності умов, Аозволяє не рахуватися з дефектами з метою захисту обороту. У такий спосіб досягаються насліАки, що за певних умов перетворюють угоду в Аійсну. Це зумовлено публічним інтересом Ао Аинамічності обороту за рахунок пожертви статичного інтересу щодо збереження непорушності правового становища. Інакше кажучи, йдеться про Аосягнення своєріАного балансу заради захисту матеріального обігу, при цьому, звісно ж, якісь суспільні інтереси, які заслуговують на захист, піАлягають ущемленню. Відтак Аля вирішення проблеми в подібний спосіб шляхом встановлення якихось запобіжників сліА враховувати головний момент: вказаний захист видимості може застосовуватися мише тоді, коли цього потребують інтереси суспільства.

Але в будь-якому разі видимість права прикриває в комерційному оброті дефекти не фактичного складу, а умови Аійсності правовіАношення. При цьому правилом є те, що відсутність Аієздатності відчужувача може бути за певних умов компенсована Аобросовісністю набувача. Та цей результат Аосягається не завжди. Так, відсутність речово-правової угоди не може бути замінена доброю совістю окупанта, якщо вона була укладена без наявності згоди сторін або внасліАок помилки чи обману. Як бачимо, позитивний Аля обороту результат виАимості права настає залежно не віА об'єктивної наявності умов Аійсності відчуження речі, а пов'язаний із тим що набувач суб'єктивно повірив в їхнє існування. При цьому не має вирішального значення той факт, чи була об'єктивна виАимість права створена власником, чи неуповноваженим традентом. ОАночасно законодавець не вимагає, щоб відчужувач Аоказував наявність у нього права у вигляді його видимості, закон навіть не вказує на обов'язковість фактичного володіння річчю з боку традента. Аля набрання видимістю належної Аієвості Аостатньо, щоб віАчужувач мав ознаки володіння та також, принаймні, зовнішню видимість правомочності. За таких обставин законодавство надає видимості права реального характеру. Саме реальність подібної видимості є належним обґрунтуванням bona fides окупанта, що формує його специфічний правовий статус як власника за правилом ст. 330 ЦКУ, надає йому змогу висувати наявні заперечення проти віндикації та, зрештою, набути право власності в порядку набувальної Аавності за приписом ст. 344 ЦКУ.

Разом із тим маємо обґрунтовано заперечити тезу, висловлену свого часу П. Ертманном стосовно того, що піА час отримання власності внаслідок спливу набувального строку в набувача видимість власного права перетворюється в реальне істинне право [10, с. 290-295]. Алже усвідомлювати наявність у себе видимості права, а не самого права, може лише особа, яка знає про наявність обставин Аля відсутності права - існування реального власника. Якщо ж окупант $€$ Аобросовісним і йому не відомі та не можуть бути відомими фактори, що унеможливлюють заперечення проти віндикації, він набуває власність на річ відразу в момент іï передачі. Якщо ж він знає про дефект свого володіння (наприклаА, будучи на момент заволоАіння Аобросовісним, він у подальшому Аізнався про існування законного власника, чи навіть відбувся суА, який віАмовив власнику в Аомаганні з-за спливу позовної Аавності), ні про яке усвіАомлення володільцем видимості власного права на час переходу його у власність мови йти не може. ААже набувальна Аавність має місце лише тоді, коли віАсутня можливість негайного Аобросовісного набуття. При цьому враховується тільки тривалість та безперервність володіння, і зовсім не обов'язково - добросовісність володільця. Інакше кажучи, якщо власність набувається в момент отримання майна віА неповноважного традента, це завжди відбувається на основі видимості права, але отримання права власності на базі подібної видимості Аля володільця виключається.

Bona fides $€$ характеристикою особистої повеАінки конкретної особи, це відтворює ії персональні віАносини з іншими індивіАами. А^е добра совість сама по собі аж ніяк не може створити право. Як вказують АосліАники питання, сторона, що уклала угоду з особою, яка, на її погляА, була уповноваженою на відчуження майна, захищена не тому, що вона набула відповідне право, а попри віАсутність такого права. СліА віАмітити, що Аобра совість набувача кардинально переоцінює сутність, зАавалося б, недійсного Аоговору відчуження. Саме дана властивість надає значення не технічного, а сутнісного характеру Аля подальшої 
можливості набуття права власності. Аобросовісність незаконного традента визначає такий стан свідомості особи, який характеризується вибачиивим незнанням про об'єктивні перешкоди у Аосягненні переслідуваною юридичної мети набуття права власності. Тут повністю Аіє теорія видимості, яка робить акцент на Аовірі до зовнішнього фактичного складу [4, с. 273].

Із проведеного АосліАження можна зробити певні висновки. Вирішальну роль у визначенні значення bona fides грає воля законодавця, віАтак добра совість тільки тоді грає певну юриАичну роль, коли АОзволяє протистояти волоАільцеві суб'єктивного права, і це санкціоноване законодавством. При цьому вибір грунтується на суспільній потребі в Аосягненні балансу між динамічністю віАносин та гарантією обороту, з одного боку, і стабільністю прав - з іншого. Аобра совість сприяє першому з цих чинників та протистоїть Аругому. Подібне протистояння праву власності призводить АО виникнення певного повноваження на боці добросовісного володільця і, що найголовніше, надає правову засади Аля можмивості юридичного захисту такого права. Також протистояння праву власності ефективно проявмяється у стані Аобросовісного набувача - узукапії, або Аавнісного володіння. Щодо проявів видимості права, то важливим є питання про реальність та значення ступеня Аобросовісності Аля набувача. Інакше кажучи, має існувати зовнішня подія, яка надає пануванню наА річчю конкретної видимості правомірності [11, с. 133]. У цьому сенсі в набувача має бути достатня впевненість у наявності в нього права. При цьому сліА погодитися з тезою, що наявність певних нестійких сумнівів не перешкоАжає Аобросовісності.

\section{NITEPATYPA:}

1. Скловский К.И. Применение норм о доброй совести в гражданском праве России. Хозяйство и право. 2002. № 9. С. 79-94.

2. Цивільне право України : підручник. У 2-х кн. / За ред. О.В. Дзери, Н.С. Кузнєцової. Київ : Юрінком Інтер, 2002. Книга I. 720 c.

3. Белов В. Добросовестность, разумность, справедливость как принципы гражданского права. Законодательство. 1998. № 8. С. 20-54.

4. Эннекцерус Л. Курс германского гражданского права: Пер с нем. Т. 1, полутом 1 / Под ред. И.Б. Новицкого. Иностранная литература, 1950. 483 с.

5. Скловский К. Механизм перехода права и последствия цессии. Хозяйство и право. 2002. № 2. С. 60-67.

6. Дождев Д.В. Добросовестность (bona fides) как правовой принцип / Политико-правовые ценности: история и современность / Под ред. В.С. Нерсесянца. М., Едиториал УРСС, 2000. С. 96-128.

7. Скловский К.И. Применение гражданского законодательства о собственности и владении. Практические вопросы. Москва : Статут, 2004. 234 с.

8. Амфитеатров Г.Н. Вопросы виндикации в советском праве. Советское государство и право. Москва : Наука, 1941. № 2. С. $38-47$.

9. Цікало В.І. Давність у цивільних правовідносинах : автореф. дис. ... канд. юрид. наук. Львів, 2004. 19 с.

10. Эртманн П. Основы учения о видимости права / Пер. с нем. А.А. Новицкой, Е.А. Польщиковой. Вестник гражданского права. 2011. № 4. С. 273-305.

11. Дернбург Г. Пандекты. Т. 1, ч. 2: Вещное право. Санкт-Петербург : Гос. Тип., 1905. 364 с.

\section{Гуйван Петро Амитрович \\ ЮРИАИЧНЕ ЗНАЧЕННЯ АОБРОЇ СОВІСТІ АЛЯ ААВНІСНОГО ВОЛОАІАЬЦЯ, ЙОГО ОБҐРУНТУВАННЯ З ПОЗИЦІЇ КОНЦЕПЦІї ВИАИМОСТІ ПРАВА}

Аана наукова стаття присвячена дослідженню питання про юридичне значення такої категорії правового статусу набувача чужої речі, як його добросовісність. Вивчено сутність цього явища, встановлено, що саме критерій добросовісності надає істотного значення претензіям учасників даних взаємин на набуття чи збереження приватного речового права. У праці підкреслюється, що, окрім значення доброї совісті на момент заволодіння чужою річчю, що налає правової визначеності можливості оформлення титулу і є складовою частинного фактичного складу Аля набуття власності чи права давнісного володіння, bona fides також характеризує порядок повеАінки окупанта і впродовж набувальної давності. При цьому Аобра совість тільки тоді має якісь правові наслідки, коли вона протиставлена суб'єктивному праву. За таких умов вона придбаває безпосереднє юридичне значення, в тому числі і як умова набуття та захисту права. Аобросовісність володіння чужою річчю $є$ внутрішнім показником усвідомлення певного майнового стану самим суб'єктом. У цьому сенсі у статті зроблена оцінка вказаного статусу з позицій наукової концепції про видимість права. За посилами цієї теорії давність також розглядається як наслідок видимості права, попри те, що вона виникає та триває всупереч волі учасників відносин та незважаючи на їхнє усвідомлення цього факту. ВіАтак добросовісне безперервне та відкрите володіння майном як власним упродовж строку набувальної давності найпоказовіше пов'язувалось із видимістю власності. Тож поняття добросовісності в сенсі особистісного сприйняття реально наявних ціннісних орієнтацій тісно пов'язано із принципом захисту видимості права, оскільки спрямована на усвідомлення його третіми особами. У роботі віАмічені певні відмінності піА час застосування теорії видимості права при набутті власності добросовісним набувачем віА 
неповноважного відчужувача та за набувальною Аавністю. Наголошується, що подібний механізм мусить застосовуватися під час презумування відношення до речі як власної з боку володільця рухомого майна. Але із правила повинні бути виключення, зокрема, в разі, коли у власника є підстави Аля віндикації речі.

Киючові слова: вилимість права, Аобра совість, Аобросовісний володілець.

\section{Guyvan Petro}

THE LEGAL SIGNIFICANCE OF GOOD CONSCIENCE FOR THE ANCIENT OWNER, ITS JUSTIFICATION FROM THE STANDPOINT OF THE CONCEPT OF VISIBILITY OF LAW

This scientific article is devoted to the study of the legal significance of such a category of legal status of the purchaser of another's thing, as its good faith. The essence of this phenomenon has been studied, it has been established that the criterion of good faith attaches significant importance to the claims of the participants of these relations for the acquisition or preservation of private property rights. The paper emphasizes that, in addition to the importance of good conscience at the time of possession of another's thing, which gives legal certainty the possibility of registration of the title and is part of the actual composition for the acquisition of property or the right of ancient possession, bona fides also characterizes the behavior of the occupier. In this case, good conscience only has some legal consequences when it is opposed to subjective law. Under such conditions, it acquires direct legal significance, including as a condition for the acquisition and protection of rights. Good faith possession of another's property is an internal indicator of the subject's awareness of a certain property status. This sense, the article assesses this status from the standpoint of the scientific concept of the visibility of law. According to this theory, prescription is also considered as a consequence of the appearance of law, however, because it arises and lasts against the will of the parties and despite their awareness of this fact. Therefore, bona fide continuous and open possession of property as one's own, during the acquisition period, was most significantly associated with the appearance of property. Therefore, the concept of good faith, in the sense of personal perception of real values, is closely related to the principle of protection of the appearance of law, as it is aimed at understanding it by third parties. The paper notes certain differences in the application of the theory of the appearance of the right in the acquisition of property by a bona fide purchaser from an unauthorized alienator and the acquisitive prescription. It is emphasized that such a mechanism must be used in presuming the attitude to the thing as its own, by the holder of movable property. But there should be exceptions to the rule, in particular, if the owner has grounds for vindication of the thing.

Key words: visibility of law, good conscience, bona fide owner. 